\title{
PENINGKATAN HASIL BELAJAR MELALUI PEMBELAJARAN KOOPERATIF TIPE STAD PADA PEMBELAJARAN DASAR SINYAL VIDEO
}

\author{
Santi Utami \\ Kompetensi Keahlian Audio Video, SMKN 1 Saptosari \\ E-mail: san_unt@yahoo.com
}

\begin{abstract}
This study aims at improving the student's learning outcomes through the cooperative learning strategy with Student Teams Achievement Division (STAD) at SMKN 1 Saptosari. This was classroom action research (CAR) consisting of planning, action, observation, and reflection. The research subjects were the grade $X$ students of Audio Video Engineering A. The data collection technique used the documentation of daily tests to show the improvement. The data was analysed with descriptive statistics. This study consisted of three cycles. The mean of test results for the first, second and third cycles were 7.06, 5.9 and 7.09 respectively. It showed that the cooperative learning strategy with STAD could improve the students' achievement to fulfill the Minimum Mastery Criterion (MMC).
\end{abstract}

\section{Keywords: Basic Video Signal, Cooperative Learning, Learning Outcomes}

\begin{abstract}
ABSTRAK
Penelitian ini bertujuan meningkatkan hasil belajar siswa melalui strategi pembelajaran kooperatif tipe Student Teams Achievement Division (STAD) di Sekolah Menengah Kejuruan Negeri 1 Saptosari. Pendekatan yang dilakukan dalam penelitian ini adalah kuantitatif dengan Penelitian Tindakan Kelas (PTK) yang terdiri atas perencanaan, pelaksanaan, pengamatan dan refleksi. Subyek penelitian siswa kelas X Teknik Audio Video A di SMKN 1 Saptosari. Teknik pengumpulan data menggunakan dokumentasi nilai ulangan harian yang diharapkan mampu menunjukkan adanya perubahan dari tindakan yang diberikan. Data yang diperoleh dianalisis dengan statistik deskriptif. Penelitian ini terdiri dari tiga siklus. Pada siklus pertama rerata nilai ulangan harian siswa sebesar 7,06 dan rerata nilai ulangan harian pada siklus kedua sebesar 5,9 sedangkan rerata nilai di siklus ketiga sebesar 7.09. Dari hasil penelitian tersebut maka dapat disimpulkan bahwa pembelajaran kooperatif tipe STAD mampu meningkatkan hasil belajar siswa hingga memenuhi Kriteria Ketuntasan Minimal (KKM).
\end{abstract}

Kata kunci: Dasar Sinyal Video, Hasil Belajar, Pembelajaran Kooperatif

\section{PENDAHULUAN}

Pendidikan merupakan cerminan kemajuan suatu bangsa. Semakin tinggi budaya suatu bangsa, semakin tinggi pula tingkat pendidikan bangsa tersebut. Bangsa yang besar adalah bangsa yang memperhatikan pendidikan warga negaranya. Undang-undang No.20 tahun 2003 tentang Sistem Pendidikan Nasional/Sisdiknas (Depdiknas, 2003) menyatakan bahwa pendidikan adalah usaha sadar dan terencana untuk mewujudkan suasana belajar dan proses pembe- lajaran agar peserta didik secara aktif mengembangkan potensi dirinya untuk memiliki kekuatan spiritual keagamaan, pengendalian diri, kepribadian, kecerdasan, akhlak mulia serta ketrampilan yang diperlukan dirinya, masyarakat, bangsa dan negara.

Dalam UU No.20 Tahun 2003 tentang Sisdiknas pasal 14 dan diperinci lagi pada pasal 18 ayat 3 yang berbunyi "Pendidikan Menengah berbentuk Sekolah Menengah Atas (SMA), Madrasah Aliyah (MA), Sekolah Menengah Kejuruan (SMK) dan Madrasah Ali- 
yah Kejuruan (MAK), atau bentuk lain sederajat". SMK adalah sekolah yang membekali anak didiknya dengan berbagai macam ketrampilan sesuai program keahliannya. Prinsip pendidikan kejuruan menurut Prosser dalam bukunya yang berjudul "Vocational Education in a Democracy" poin 1 dan 2 yang dikutip oleh Djojonegoro (1998: 38) menyatakan bahwa (1) pendidikan kejuruan akan efisien apabila disediakan lingkungan belajar yang sesuai dengan semisal replika dari lingkungan dimana mereka kelak akan bekerja dan (2) latihan kejuruan yang efektif hanya dapat diberikan jika tugas-tugas yang diberikan di dalam latihan memiliki kesamaan operasional, dengan peralatan yang sama dan dengan mesin-mesin yang sama dengan yang akan digunakan di dalam kerjanya kelak.

SMKN 1 Saptosari adalah salah satu SMK di Gunungkidul yang memiliki beberapa permasalahan antara lain ketidakjujuran siswa yang terlihat pada saat ulangan, perilaku siswa di kelas yang cenderung bermalas-malasan dan tidak memperhatikan apa yang disampaikan guru serta hasil belajar yang belum memenuhi Kriteria Ketuntasan Minimal (KKM). Hal ini merupakan permasalahan yang ada di kelas dan harus segera diselesaikan. Salah satu cara yang ditempuh untuk menyelesaikan masalah ini adalah dengan penggunaan strategi pembelajaran kooperatif.

Slavin (2005: 1) menerangkan bahwa pembelajaran kooperatif dapat diaplikasikan untuk semua kelas, yaitu: kelas khusus untuk anak berbakat, kelas pendidikan khusus, kelas dengan kecerdasan rata-rata dan sangat diperlukan dalam kelas heterogen dengan berbagai tingkat kemampuan. Slavin (2005: 1) menambahkan bahwa pembelajaran kooperatif dapat diaplikasikan untuk semua kelas dan dapat menumbuhkan motivasi dari dalam diri siswa. Pembelajaran kooperatif juga mampu menumbuhkan motivasi dalam diri siswa seperti yang diungkapkan Slavin (2005: 34) bahwa dari perspektif motivasional struktur tujuan kooperatif menciptakan sebuah situasi dimana satusatunya cara anggota kelompok dapat meraih tujuan pribadi mereka adalah jika kelompok mereka sukses. Killen (2009: 211-212) memaparkan pembelajaran kooperatif adalah strategi mengajar yang paling banyak diteliti terutama dari segi kemanfaatan dan keefektifan. Pembelajaran kooperatif terjalin kerjasama untuk mencapai tujuan bersama. Dell (2007: 317) menjelaskan bahwa pembelajaran kooperatif adalah pendekatan pembelajaran yang menyediakan kesempatan dan pengelolaan kelompok belajar, sedangkan Strommen (1995: 24) menyatakan bahwa strategi pembelajaran kooperatif melibatkan kelompok-kelompok kecil yang dalam satu kelompok terdiri dari siswa dengan prestasi tinggi, sedang dan rendah. Borich (2007: 371) menerangkan bahwa pembelajaran kooperatif mampu menumbuhkan kemandirian siswa dalam proses pembelajaran. Pembelajaran kooperatif sebagai alternatif untuk kemampuan kelompok khususnya menumbuhkan bakat siswa (Slavin, 1988: 31). Roger (2009: 1) memaparkan dalam pembelajaran kooperatif terjadi interaksi yang positif. Dapat disimpulkan dari berbagai paparan tersebut bahwa pembelajaran kooperatif merupakan pembelajaran yang dapat diterapkan di semua kelas dan menumbuhkan motivasi, kemandirian dan bakat siswa melalui kerjasama kelompok dalam mencapai tujuan bersama (belajar).

Slavin (2005: 11) mengatakan bahwa pembelajaran kooperatif memiliki lima jenis yaitu: (1) Students Team Achievement Division/ STAD, (2) Team Game Tournament/ TGT, (3) Jigsaw II, (4) Team Accelerated Instruction/ TAI, (5) Cooperative Integrated Reading and Composition/CIRC. Dari kelima jenis pembelajaran kooperatif tersebut, STAD dinilai dapat mengatasi permasalahan pembelajaran di kelas. Ide utama pembelajaran metode STAD adalah untuk memotivasi siswa agar saling membantu dalam memahami sebuah materi pelajaran dan saling membantu dalam menyelesaikan masalah. Agar mendapatkan penghargaan dari guru maka anggota tim harus memperoleh nilai yang tinggi dalam evaluasi yang diberikan. Oleh karena itu kerjasama tim dan saling memotivasi akan mengantarkan siswa pada kesuksesan. 
Lima komponen pembelajaran kooperatif tipe STAD menurut Slavin adalah: (1) presentasi kelas, (2) kerja tim, (3) kuis, (4) penghargaan individu dan (5) penghargaan kelompok.

Suprijono (2010: 3) mendefinisikan bahwa belajar sebagai kegiatan psiko-fisik-sosio untuk menuju perkembangan pribadi selanjutnya. Belajar merupakan perubahan tingkah laku akibat pengalaman dan lingkungan. Proses perubahan tingkah laku seseorang tidak dapat disaksikan tetapi dilihat dari gejala-gejala perubahan yang tampak (Sanjaya, 2007: 112). Hasil belajar sebagaimana dipaparkan Sudjana (2009: 111) adalah kemampuan yang dimiliki siswa setelah siswa tersebut menerima pengalaman belajar. Sedangkan menurut Jenkins dalam Uno (2011: 17) hasil belajar adalah pernyataan yang menunjukkan tentang apa yang mungkin dikerjakan siswa sebagai hasil dari kegiatan belajar. Kemampuan siswa dalam belajar dapat dilihat dari aspek kognitif, afektif dan psikomotorik. Bloom (1956: 7) mengungkapkan bahwa "Our original plans called for a complete taxonomy in three major parts, the cognitive, the affective and the psychomotor domains" atau dinyatakan bahwa pada awalnya taksonomi terdiri dari tiga ranah yaitu kognitif, afektif dan psiko-motorik. Dari ketiga ranah tersebut terdapat beberapa tingkatan. Dalam penelitian ini hasil belajar yang diukur ada pada ranah kognitif dengan tingkatan yang terdiri atas: (1) pengetahuan, (2) pemahaman, (3) penerapan, (4) analisa, (5) sintesa dan (6) evaluasi.

\section{METODE}

Penelitian ini merupakan Penelitian Tindakan Kelas (Classroom Action Research). Penelitian Tindakan Kelas bertujuan untuk meningkatkan kualitas proses dan hasil pendidikan dengan memberikan perlakuan tertentu kepada siswa. Sebelum penelitian dilaksanakan, peneliti terlebih dahulu melakukan observasi kelas untuk mengetahui kondisi kelas, interaksi antara guru dengan siswa, serta berupaya menemukan berbagai permasalahan selama proses pembelajaran berlangsung. Selanjutnya dicari akar penyebab permasalahan dan rencana penyelesaian yang akan menjadi acuan awal penelitian. Hasil belajar siswa diketahui dari hasil tes atau ulangan harian setiap kompetensi dasar kemudian dilakukan analisis.

Penelitian ini dilaksanakan pada kelas $\mathrm{X}$ Audio Video A SMKN 1 Saptosari. Lokasi sekolah berada di Jl. Wonosari-Panggang, km 22, Kepek, Saptosari, Gunung Kidul. Subyek penelitian adalah siswa kelas X AV A Teknik Audio Video yang berjumlah 28 siswa yang diamati tingkah lakunya di saat pembelajaran berlangsung. Kelas XAV A terdiri dari 22 siswa laki-laki dan 6 siswa perempuan. Di kelas ini prestasi siswa, latar belakang keluarga dan kemampuan belajar siswa sangat beragam. Sampel dipilih dengan menggunakan teknik purposive sampling yaitu teknik pengambilan sampel sumber data dengan pertimbangan tertentu. Sampel dalam penelitian ini berfungsi untuk mendapatkan informasi yang maksimum, bukan untuk digeneralisasikan (Sugiyono, 2007: 301). Pertimbangan dalam penentuan sampel ini berdasarkan pada keberagaman nilai siswa dan kondisi kelas X AV A yang kurang dinamis dalam pembelajaran.

Penelitian ini merupakan penelitian tindakan kelas yang berupaya untuk mengubah kondisi kelas sekarang ke arah kondisi yang diharapkan menjadi lebih baik dan dinamis. Dalam penelitian ini peneliti sekaligus menjadi guru namun juga tetap melaksanakan pola kerja sama (kolaborasi) terutama dalam melaksanakan penelitian (melaksanakan tindakan, observasi, merekam data, evaluasi dan refleksi). Untuk itu, peneliti berkolaborasi dengan guru serumpun.

Penelitian tindakan kelas ini menerapkan model spiral dari Kemmis dan Taggart yang dikemukakan oleh Mulyasa (2011: 182) yang membagi prosedur penelitian tindakan dalam empat tahap kegiatan pada satu putaran (siklus) yaitu perencanaan, tindakan observasi dan refleksi dalam suatu spiral yang saling terkait. Tindakan dan keberhasilan pada siklus pertama harus diobservasi, dievaluasi dan kemudian direfleksi untuk merancang tindakan pada sik- 
lus kedua dan begitu seterusnya hingga diperoleh peningkatan kemajuan yang diinginkan. Tahapan penelitian tindakan yang dilakukan adalah sebagaimana ditunjukkan pada Gambar 1 berikut ini.

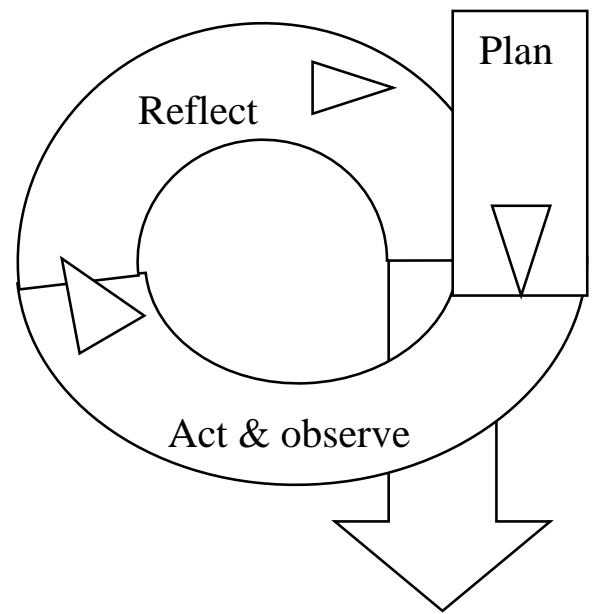

\section{Gambar 1. Tahapan Kegiatan Penelitian Tindakan Kelas}

Pada tahap persiapan, peneliti melakukan observasi tentang perilaku siswa terutama motivasi dan kemandirian siswa, dan mengamati hasil belajar siswa untuk menentukan pembagian kelompok belajar. Observasi awal digunakan untuk mengetahui tingkat motivasi dan kemandirian siswa dalam pembelajaran dan sebagai acuan peningkatan yang terjadi setelah penggunaan STAD. Observasi ini juga dibutuhkan untuk menentukan langkah-langkah dalam pembelajaran kooperatif tipe STAD. Selain observasi kelas, dibutuhkan dokumentasi nilai siswa untuk acuan pembentukan kelompok belajar STAD. Langkah selanjutnya setelah observasi adalah menentukan rencana tindakan berupa tindakan siklus1.

Langkah pertama dalam siklus pertama adalah persiapan yang terdiri atas beberapa kegiatan yaitu: (1) membuat Rencana Pelaksanaan Pembelajaran (RPP) tentang materi dasar sinyal video sesuai dengan model pembelajaran yang akan digunakan, RPP disusun oleh peneliti dan dikonsultasikan dengan pakar/ ahli terkait penelitian yang akan dilakukan; (2) mempersiapkan lembar penilaian: (3) membagi kelompok berdasarkan perbedaan prestasi, jenis kelamin, latar belakang budaya; dan (4) mempersiapkan soal tes untuk siswa; yaitu tes yang akan diberikan pada akhir pembelajaran dan akhir siklus.

Tahap kedua yaitu pelaksanaan tindakan yang mengacu pada perencanaan yang ada dan pelaksanaannya bersifat fleksibel dan terbuka terhadap perubahan-perubahan. Selama proses pembelajaran berlangsung, guru melaksanakan pembelajaran sesuai dengan RPP yang telah disusun dan disesuaikan dengan tujuan penelitian yang ingin dicapai. Selama proses pembelajaran, kolaborator mengamati interaksi guru dan siswa dalam lembar observasi kelas. Dalam pembelajaran yang menggunakan metode STAD, kelas dibagi menjadi delapan kelompok dan masing-masing kelompok terdiri dari empat orang siswa. Pembagian kelompok mengacu pada prestasi siswa dan jenis kelamin. Setiap kelompok terdiri dari siswa yang memiliki prestasi tinggi, menengah dan rendah serta terdiri dari siswa laki-laki dan perempuan. Tahap ketiga adalah observasi yang dilaksanakan selama dan sepanjang proses pembelajaran berlangsung. Tahap terakhir dalam siklus pertama ini adalah refleksi yaitu dengan mengolah data yang telah diperoleh dari observasi. Dari hasil evaluasi tersebut kemudian dibuat rancangan untuk pelaksanaan siklus kedua.

Pada siklus kedua, tahapan kegiatan yang dilakukan sama dengan siklus pertama yaitu persiapan, pelaksanaan, observasi dan refleksi. Tahap pertama adalah persiapan yang mengacu pada hasil refleksi yang telah dilakukan pada siklus pertama. Persiapan pada siklus II ini meliputi merevisi RPP, mempersiapkan lembar penilaian, membuat kelompok baru dengan memperhatikan perbedaan tingkat prestasi siswa (tinggi, sedang dan rendah) dan jenis kelamin dan mempersiapkan soal tes. Tahap kedua adalah pelaksanaan tindakan yang dilakukan sebagaimana pelaksanaan tindakan pada siklus pertama. Pembelajaran dilaksanakan mengacu pada RPP yang telah dibuat. Dari siklus II ini diharapkan ada peningkatan hasil belajar siswa. Tahap ketiga adalah observasi yang dilaksanakan dengan tes kemampuan 
siswa. Tahap terakhir adalah refleksi dimana dalam siklus II ini digunakan sebagai pembanding hasil dari siklus I. Apabila belum terjadi peningkatan yang signifikan maka siklus bisa diulang.

Instrumen pengumpulan data dalam penelitian ini meliputi: (1) dokumentasi yang merupakan dokumentasi nilai siswa sebagai dasar pembagian kelompok STAD dan pengukuran keberhasilan penelitian. Setelah kegiatan dalam kelompok berjalan, kemudian dilakukan tes tertulis untuk mengetahui siswa dengan nilai tertinggi dan terendah. Nilai siswa juga dijadikan sebagai penentu kelompok terbaik dalam kelas tersebut. Kelompok terbaik akan mendapatkan suatu penghargaan dari guru. Hal ini dimaksudkan untuk memotivasi siswa agar belajar dengan lebih baik, dan (2) Rencana Pelaksanaan Pembelajaran (RPP) yang digunakan sebagai panduan guru dalam melaksanakan pembelajaran di dalam kelas. Dalam penelitian ini RPP digunakan untuk memberikan perlakuan terhadap siswa yaitu dengan metode STAD.

Analisis yang digunakan adalah analisis deskriptif yaitu sebuah analisis untuk menggambarkan data berdasar pada perhitungan mean, median, dan modus. Modus merupakan nilai yang sering muncul dalam kelompok tersebut. Mean merupakan nilai rata-rata atas kelompok tersebut. Rumus dari mean adalah sebagai berikut:

$$
M e=\frac{\sum x i}{n}
$$

Median merupakan nilai tengah dari sekelompok data yang telah disusun urutannya dari yang terkecil hingga yang terbesar.

\section{HASIL DAN PEMBAHASAN}

Tahap-tahap Penelitian Tindakan Kelas di siklus I meliputi: (1) persiapan yang dilakukan dengan pembuatan RPP menggunakan format yang telah disetujui sekolah, (2) pelaksanaan dilakukan dalam pembelajaran Menguasai Dasar Sinyal Video yang dilakukan sesuai jadwal sekolah yaitu hari Senin menggunakan metode kooperatif tipe STAD maka terlebih dahulu membagi kelas menjadi beberapa kelompok kecil berdasarkan prestasi belajar, dan tiap kelompok harus memuat siswa laki-laki dan siswa perempuan, (3) observasi dimana dalam kegiatan ini, guru mengawasi jalannya diskusi, memimpin presentasi kelompok dan memberikan penilaian, dan (4) refleksi adalah tahapan dimana hasil penelitian dianalisis kemudian dilakukan tindakan koreksi terhadap kekurangan yang terjadi.

Hasil observasi di kelas adalah sebagai berikut: (1) terdapat kesuaian antara pembagian waktu di RPP dengan lembar observasi kelas, (2) ada satu aktifitas yang tidak dilakukan guru yaitu tidak mencatat siswa yang tidak membawa artikel sehingga belum ada reward dan punishment pada siswa supaya siswa lebih disiplin dalam pembelajaran, (3) presensi tidak harus satu persatu siswa karena sudah cukup mengenal siswa.

Masing-masing kelompok kecil berusaha memperoleh skor kelompok untuk mendapat penghargaan sebagai tim terbaik. Skor kelompok diperoleh dari akumulasi skor setiap anggota kelompok. Rerata nilai kelas di siklus pertama ini sebesar 7.06 dengan nilai tertinggi 8.0 dan nilai terendah 5.10. Siswa belajar lebih menyenangkan karena terjadi kompetisi antar siswa dan juga kompetisi antar kelompok.

Pelaksanaan siklus I masih ditemukan beberapa kekurangan yaitu: (1) pembelajaran dengan strategi STAD kurang berjalan efektif karena adanya beban menyusun artikel. Dalam hal ini siswa mendapatkan beban untuk mencari bahan belajar sendiri dengan tujuan agar siswa mandiri dalam menentukan bahan pelajaran yang sesuai dengan kurikulum yang sudah ditetapkan. Hasilnya, masih banyak siswa yang tidak mempedulikan hal ini. Oleh karena itu untuk mengatasi masalah tersebut diperlukan sebuah solusi. Adapun solusi yang dicapai ada dua pilihan yaitu, (a) artikel diberikan oleh guru atau (b) siswa tetap diharuskan membawa artikel dengan syarat apabila ada siswa yang tidak membawa artikel maka konsekuensi harus ditanggung oleh semua anggota kelompok. Akhirnya ditetapkan pilihan yang kedua, karena 
pilihan ini dianggap mampu untuk meningkatkan tingkat kemandirian siswa yang harus bertanggung jawab atas tugasnya, (2) artikel yang dibawa siswa masih jauh dari materi yang diharapkan. Siswa yang sudah membawa artikel dengan tingkat kesesuaian materi yang bagus, perlu diberikan reward atau hadiah. Hal ini bertujuan supaya siswa benar-benar serius dalam mencari bahan pelajaran. Selain itu, guru juga wajib mengontrol ketercapaian siswa dalam mencari bahan ajar.

Pada siklus kedua ini tahapan yang dilalui sama seperti pada siklus pertama yaitu: (1) persiapan yang dilakukan dalam siklus II ini adalah menyiapkan RPP sesuai dengan format yang telah disetujui oleh Kepala Sekolah, (2) pelaksanaan dalam tahap ini, dimulai dengan pembagian kelompok berdasarkan pada hasil tes sebelumnya dan juga dalam satu kelompok harus ada siswa perempuannya, (3) observasi dengan mengamati jalannya pembelajaran di kelas, apakah sesuai RPP atau tidak dan hasil dari observasi kelas juga diperoleh hasil penelitian, dan (4) refleksi dengan cara melakukan perbandingan hasil yang diperoleh pada siklus pertama dengan hasil pada siklus kedua.

Hasil siklus kedua diperoleh rerata nilai kelas adalah 5.9 dengan nilai tertinggi 9.0 dan nilai terendah 2.0. Hasil dari siklus kedua ini ternyata banyak siswa yang tidak lulus KKM dan harus diadakan remidial. Dalam pelaksanaan siklus kedua tidak dimunculkan tahapan presentasi sehingga guru tidak bisa mengkonfirmasi pengetahuan siswa. Oleh karena itu pada siklus berikutnya guru harus melaksanakan pembelajaran dengan metode STAD sesuai dengan tahapan yang ditetapkan. Refleksi siklus kedua dijadikan bahan perbaikan untuk siklus ketiga sehingga diharapkan terjadi peningkatan yang signifikan.

Pelaksanaan siklus ketiga diawali dengan presentasi oleh guru, dilanjutkan dengan diskusi kelompok dengan tema pembahasan yang sudah ditentukan guru. Tahapn selanjutnya adalah presentasi kelompok dilanjutkan tanya jawab sehingga suasana kelas menjadi dinamis, peran guru dalam tahapan ini sebagai moderator diskusi. Setelah diskusi dan pengambilan kesimpulan, diskusi dilanjutkan dengan kuis kelompok dan tes individu. Kelompok yang dapat menjawab pertanyaan dari guru diberikan penghargaan. Hasil tes siswa menunjukkan bahwa terjadi peningkatan yang signifikan dibandingkan siklus kedua. Dari siklus ini nilai rerata siswa sebesar 7.09, nilai minimal 4.0 dan nilai maksimal 9.3.

Hasil belajar siswa sebelum diterapkan metode STAD mencapai rerata 6,86 dan masih banyak siswa yang belum memenuhi KKM. Setelah dilaksanakan metode STAD pada siklus pertama rerata nilai kelas 7.06 dan pada siklus kedua terjadi penurunan nilai siswa dengan rerata nilai 5.9 dan dilanjutkan pada siklus ketiga sehingga diperoleh rerata nilai menjadi 7.09. Pada pembelajaran kooperatif tipe STAD guru dan siswa harus displin dalam melaksanakan setiap tahapan. Adapun perbandingan nilai hasil belajar siswa pada siklus pertama, kedua dan ketiga disajikan Tabel 1 berikut ini.

Tabel 1. Data Hasil Belajar Siswa

\begin{tabular}{cccc}
\hline $\begin{array}{c}\text { Sumber } \\
\text { Statistik }\end{array}$ & Siklus 1 & Siklus 2 & Siklus 3 \\
\hline $\mathrm{N}$ & 28 & 28 & 28 \\
$\mathrm{X}$ & 7.06 & 5.9 & 7.09 \\
Min & 5.10 & 2.0 & 4.0 \\
Max & 8.0 & 9.0 & 9.3 \\
\hline
\end{tabular}

Beberapa pengetahuan yang diperoleh peneliti dari penelitian terdiri atas: (1) banyaknya siklus yang digunakan dalam pelaksanaan Penelitian Tindakan Kelas menyesuaikan dengan hasil yang diperoleh, selama belum dapat mendapatkan hasil yang diharapkan maka siklus dapat ditambah, (2) rotasi kelompok dalam pembelajaran kooperatif tipe STAD dilakukan setelah siswa mencapai titik jenuh yaitu berlangsung selama tiga hingga lima kali pertemuan sehingga dapat diperoleh hasil yang lebih memuaskan, (3) semua tahapan dalam pembelajaran kooperatif tipe STAD harus dilaksanakan dengan disiplin, sehingga bisa dibuktikan kebenaran teorinya, dan (4) pembelajaran 
kooperatif tipe STAD mampu meningkatkan hasil belajar siswa pada Standard Kompetensi Dasar Sinyal Video.

\section{SIMPULAN}

Berdasarkan data dan pembahasan yang diperoleh, maka dalam penelitian ini dapat disimpulkan bahwa pembelajaran kooperatif tipe STAD mampu meningkatkan hasil belajar siswa. Beberapa hal yang perlu diperhatikan antara lain penentuan siklus penelitian harus disesuaikan dengan target yang ingin dicapai, perlu diperhatikan rotasi kelompok yang sebaiknya dilakukan setelah 3-5 kali pertemuan, sehingga pelaksanaan pembelajaran kooperatif tipe STAD memerlukan waktu yang lebih lama. Penelitian ini menunjukkan bahwa pembelajaran kooperatif tipe STAD mampu meningkatkan hasil belajar siswa pada Standar Kompetensi Dasar Sinyal Video.

Berdasarkan simpulan dan implikasi diatas berikut ada beberapa saran untuk peningkatan motivasi, kemandirian dan hasil belajar siswa menggunakan pembelajaran kooperatif tipe STAD antara lain: (1) sekolah diharapkan memberikan kesempatan kepada para guru untuk mengembangkan diri ke luar maupun ke dalam. Pengembangan diri ke luar artinya sekolah memberikan kesempatan kepada guru untuk mengembangkan potensinya dengan cara mengikuti seminar atau diklat yang dilaksanakan untuk meningkatan kualitas pembelajaran. Pengembangan diri ke dalam dimaksudkan guru dapat melakukan penelitian di sekolah untuk meningkatkan kualitas siswa; (2) guru diharapkan mampu mengidentifikasi permasalahan yang terjadi di kelas terutama dalam pembelajaran sehingga masalah tersebut dapat diatasi. Sebagai pendidik, guru diharapkan mampu mengembangkan kemampuan mengajar terutama dalam hal penggunaan strategi pembelajaran. Permasalahan yang terjadi di kelas dapat diatasi dengan pendekatan belajar siswa aktif berupa diskusi kelompok dan kompetisi sehat siswa dalam penguasaan materi tertentu. Dalam melakukan sebuah penelitian harus displin dalam menjalankan semua prosedur yang berlaku; dan (3) bagi peneliti lain yang membaca artikel penelitian ini dan ingin mengembangkannya maka hendaklah benar-benar diperhitungkan waktu pelaksanaannya karena pembelajaran STAD memerlukan waktu lama untuk mencapai hasil terbaik. Selain itu, dapat dilakukan dalam skala yang lebih besar dan pembelajaran teori beserta praktik.

\section{DAFTAR RUJUKAN}

Bloom, B. S. 1956. A Taxonomy for Learning Teaching. New York: McKay

Borich, G. D. 2007. Effective Teaching Methods. Ohio: Pearson Prentice Hall

Dell'Olio, J. M., dan Donk, T. 2007. Models of Teaching. Thousand Oaks: Sage Publications

Depdiknas. 2003. Undang-undang RI, Nomor 20, Tahun 2003, tentang Sistem Pendidikan Nasional

Djojonegoro, Wardiman. 1998. Pengembangan Sumber Daya Manusia melalui SMK. Jakarta: Jaya Agung Offset

Killen, R. 2009. Effective Teaching Strategies: Lesson from Research and Practice. Victoria: Cengage Learning Australia

Mulyasa, E. 2011. Praktik Penelitian Tindakan Kelas. Bandung: Remaja Rosdakarya

Roger, T dan David, W.J. 2009. An Overview of Cooperative Learning. Diambil dari http://www.cooperation.org/pages/overvi ewpaper.html pada tanggal 20 Agustus 2012

Sanjaya, W. 2007. Strategi Pembelajaran BerOrientasi Standard Proses Pendidikan. Jakarta: Kencana Prenada Media 
Slavin, E. Robert. 1988. Cooperative Learning (Theory, Research and Practice).London: Allyn and Beacon 2005. Cooperative Learning. (Terjemahan Nerulita Yusron). London: Allyn and Bacon

Strommen, E. 1995. Cooperative Learning. Journal of Electronic Learning.Vol. 14, 24-35

Sudjana, Nana. 2009. Dasar-Dasar Proses Belajar Mengajar. Bandung: Grasindo
Sugiyono. 2007. Metode Penelitian Pendidikan.

Bandung: Alfabeta

Suprijono, Agus. 2010. Cooperative Learning, Teori dan Aplikasi PAIKEM. Yogyakarta: Pustaka Pelajar

Uno, Hamzah B. 2011. Teori Motivasi dan Pengukurannya. Jakarta: Bumi Aksara 